\title{
Distortion and dissatisfaction with body size per the demographic and academic characteristics and the nutritional status of university students
}

\author{
Adrielly dos Santos ${ }^{1}$ (D), Wanderson Roberto da Silva ${ }^{1}$ (D), Moema de Souza Santana ${ }^{1}$ (D), \\ Juliana Alvares Duarte Bonini Campos ${ }^{1 *}$ (1) \\ ${ }^{1}$ Programa de Pós-graduação em Alimentação e Nutrição, Faculdade de Ciências Farmacêuticas, Universidade Estadual de \\ São Paulo (UNESP), Araraquara, SP, Brasil \\ *Corresponding author: juliana.campos@unesp.br
}

\begin{abstract}
To identify the prevalence of distortion and dissatisfaction with the body size of Brazilian university students, and establish their relationship with the demographic and academic characteristics and the anthropometric nutritional status. The sample consisted of students from a public university in the state of São Paulo. The Figure Rating Scale (FRS) for Brazilian adults was used as an instrument. The participants selected the figure that corresponded to the current body and another one for the desired body. The prevalence of distortion and dissatisfaction with body size was calculated with $95 \%$ confidence interval $(95 \% \mathrm{Cl})$. The association between the variables was evaluated by the Chi-Square Test $\left(\chi^{2}\right)$. The significance level of $5 \%$ was adopted. A total of 356 students (women $=71.63 \%$ ) with a mean age of $20.95(S D=2.55)$ years participated. The prevalence of distortion and dissatisfaction with body size was $73.03 \%$ (95\% Cl=68.23-77.83) and $79.49 \%$ (95\% $\mathrm{Cl}=75.3-83.68)$, respectively. There was a high prevalence of distortion with body size among individuals with low weight $\left(\chi^{2}=9.523, p=0.009\right)$. Students who distorted the body size $(52.31 \%[95 \%$ $\mathrm{Cl}=47.12-57.50])$ underestimated their body size. The type of distortion was related to sex $\left(\chi^{2}=26.35, p<0.001\right)$, physical activity $\left(\chi^{2}=4.51, p=0.034\right)$, use of supplements $\left(\chi^{2}=4.62, p=0.032\right)$, and the anthropometric nutritional status $\left(\chi^{2}=9.05, p=0.011\right)$. Students dissatisfied with the body (58.66\% [95\% Cl=52.92-64.40]) wished to reduce the body size. The type of dissatisfaction was related to $\operatorname{sex}\left(\chi^{2}=5.79, p=0.016\right)$ and anthropometric nutritional status $\left(\chi^{2}=89.83, p<0.001\right)$. The prevalence of body size underestimation was higher among men, students who practice physical activity, subjects using dietary supplements and underweight individuals. The wish to decrease body size was higher among women and overweight/obese individuals.
\end{abstract}

Keywords: Body Distortion. Body Dissatisfaction. Body Size. University Students.

\section{How to cite}

Santos A, Silva WR, Santana MS, Campos JADB. Distortion and dissatisfaction with body size per the demographic and academic characteristics and the nutritional status of university students. Rev Ciênc Farm Básica Apl. 2020;41:e665. https://doi.org/10.4322/2179-443X.0665.

\section{INTRODUCTION}

The body image is a multifactorial construct that refers to an individual's mental representation about his/her own body (Cash \& Smolak, 2011; Grogan, 2016). According to Cash \& Smolak (2011), this concept can be investigated from the perceptual and attitudinal 
dimensions. The perceptual dimension encompasses an individual's mental representation of the body, while the attitudinal dimension involves thoughts, feelings, and behaviors related to the perceived image. Thus, the body image involves several aspects that go beyond physiological factors and also included psychosocial ones.

Dissatisfaction with body size is an important aspect that helps to understand people's perceptions and attitudes towards their bodies (Banfield \& McCabe, 2002). It is known that currently overweight is a worldwide public health problem that affects more than 1.9 billion adults (World Health Organization, 2018) and this has contributed strongly to the body dissatisfaction in the population. However, individuals with normal weight and underweight also have been concerned with the body, showing that this problem affects people regardless of nutritional status (Banfield \& McCabe, 2002; Grogan, 2016).

Besides the dissatisfaction, the distortion with the body size can also assist in the investigation of body image. According to Kakeshita et al., (2009) the distortion with the size of the body can be obtained from the discrepancy between the perceived and the real body. The literature (Cash \& Smolak, 2011; Gardner \& Brown, 2010; Hosseini \& Padhy, 2019; Xavier et al., 2015) has been suggesting the use of the figural drawing scales, such as Figure Rating Scale (FRS) to evaluate both concepts (dissatisfaction and body distortion). The first FRS was proposed by Stunkard et al. (1983) since then, this instrument has been widely used and adapted for different samples (Coqueiro et al., 2008; Pelegrini \& Petroski, 2010; Scherer et al., 2010). In Brazil, the FRS was adapted by Scagliusi et al. (2006) for the adult female population. Subsequently, Kakeshita et al. (2009) proposed two scales of figures for both sexes, one for adults and another one for children.

The FRS for Brazilian adults was designed based on the presentation of a series of 15 figures arranged in an ascending order (varying from the skinny until the fattest shape). Each figure has a corresponding mean Body Mass Index (BMI) with a homogeneous interval of $2.5 \mathrm{~kg} / \mathrm{m}^{2}$ between the figures. The individuals are invited to point out the figure that better represents their current body and another one for the desired body. The dissatisfaction with the body size is obtained from the difference between the mean BMI corresponding to the figure pointed out for the desired body and the mean BMI corresponding to the figure pointed out for the current body. On the other hand, the distortion with the body size is calculated from the difference between the mean BMI of the figure pointed out as corresponding to the current body and the individual's real BMI (Kakeshita et al., 2009).

Regarding the evaluation of distortion and dissatisfaction with body size, Cash et al. (2004) report that these aspects can be influenced by psychological, physical, socio-cultural and behavioral factors. The literature (Amaral \& Ferreira, 2017; Modoio et al., 2011; Nikniaz et al., 2016; Radwan et al., 2019; Schumacher et al., 2010) has been investigating the relationship between these aspects and the sex, age, nutritional status, economic class, study/work environment, among others. Some authors report, for example, that women wish mainly to lose weight, while men seek weight gain in the form of muscle mass (Adami et al., 2008; Demarest \& Allen, 2000; Muth \& Cash, 1997; Nikniaz et al., 2016; Radwan et al., 2019). These studies also point out that women have a higher negative body image when compared to men and this may contribute to the development of harmful behaviors, such as disordered eating (Da Silva et al., 2020, Silva et al., 2017).

Previous studies (Maruf et al., 2014; Pereira et al., 2009; Silva et al., 2017) have shown the significant relationship between body dissatisfaction and the economic level, where individuals from higher economic classes were more dissatisfied with body-related issues. Furthermore, the literature (Bosi et al., 2006; Neighbors \& Sobal, 2007; Nikniaz et al., 2016; Radwan et al., 2019) has shown a higher prevalence of dissatisfaction with body size among individuals with overweight and obesity. In this way, the identification of factors related to both dissatisfaction and distortion with body size may be relevant in order to point out aspects that should be considered for the screening and/or treatment of individuals at risk of developing body image disorders, such as university students. 
The university environment also may influence individuals' body concerns given the sudden changes of social paradigms, high tension, and anxiety that affects mainly younger (Silva et al., 2020; Schumacher et al., 2010; Yahia et al., 2011). Tallat et al., (2017) suggest further research that explores the relationship between university environment and body image, since negative perceptions can affect students' eating behavior. In Brazil, the investigation of body image is common. Generally, studies indicate that Brazilians are increasingly concerned with body aesthetics and this has contributed to significant changes in the diet of the population that is often not always adequate (Carvalho et al., 2017; Silva et al., 2018).

\section{OBJECTIVE}

This study aimed to identify the prevalence of distortion and dissatisfaction with body size in a sample of Brazilian university students and establish their relationship with the demographic and academic characteristics and the anthropometric nutritional status.

\section{MATERIAL AND METHODS}

\section{Study and Sample Design}

This is a cross-sectional study, with non-probabilistic sampling designed by convenience. In the period from September 2015 to February 2016, all students aged 18 to 35 years enrolled in the Pharmacy-Biochemistry course of the School of Pharmaceutical Sciences of São Paulo State University (UNESP, campus Araraquara) were invited to participate in the study.

\section{Study Variables and Measure}

For sample characterization, age, sex, study schedule, labor activity together with studies, engagement in physical activities, and use of medications and dietary supplements to change the body, were collected. Individuals were classified into the economic class according to Brazil Criteria (Associação Brasileira de Empresas de Pesquisa, 2015). A trained researcher and calibrated in pilot study measured students' weight and height. The weight was measured with participants wearing light clothes and barefoot in a Filizola ${ }^{\circledR}$ electronic personal scale, with capacity for $180 \mathrm{~kg}$ and accuracy of $100 \mathrm{~g}$. The height was measured using a portable stadiometer with a scale in millimeters. Participants were asked to touch the appliance's base with their heels, glutes and shoulders with the head positioned in the Frankfurt plane (Brasil, 2011). BMI $\left(\mathrm{kg} / \mathrm{m}^{2}\right)$ was calculated from the weight $(\mathrm{kg})$ and height $(\mathrm{m})$ measures. The classification of participants' anthropometric nutritional status was carried out using the proposal of the World Health Organization (2000); Onis et al. (2007).

Distortion and dissatisfaction with body size were evaluated using the FRS proposed by Kakeshita et al. (2009). This scale is composed of 15 silhouette figures arranged independently on $12.5 \mathrm{~cm}$ (height) vs. $6.5 \mathrm{~cm}$ (width) cards. Each silhouette figure has a corresponding $\mathrm{BMI}$ mean ranging from the skinny $\left(\mathrm{BMI}=12.5 \mathrm{~kg} / \mathrm{m}^{2}\right)$ to the fatter $\left(\mathrm{BMI}=47.5 \mathrm{~kg} / \mathrm{m}^{2}\right)$, with homogeneous intervals of $2.5 \mathrm{~kg} / \mathrm{m}^{2}$ between each figure. For the investigation of the dissatisfaction with body size, participants were asked to point out the figures that better represented their "current body" and "desired body". Dissatisfaction with body size was calculated by subtracting the desired figure's BMI value from the current figure's BMI value. Students were classified as to the presence (any positive [wish to increase body size] or negative [wish to decrease body size] value) or absence (value equal to zero) of dissatisfaction with body size. For the investigation of the distortion with body size, was used two analytical strategies, the original and an alternative named "normative distortion with body size" (see Campos et al., 2020). In the original method, any difference between the mean BMI of the figure pointed out as corresponding to the current body and the individual's real BMI was considered as a distortion with body size. On the other hand, in the alternative method, when the 
difference between BMI values (figure and real) was lower or higher than $1.25 \mathrm{~kg} / \mathrm{m}^{2}$ a normative distortion with body size was found (i.e., non-problematic). We used two analytical strategies because in the original proposal any difference is considered as distortion, which can overestimate the prevalence. In this way, individuals were classified as having (present) or not having (absent) distortion with body size only for absolute values below (underestimating) or above (overestimating) of $1.25 \mathrm{~kg} / \mathrm{m}^{2}$.

\section{Pilot Study}

A pilot study with 29 students (mean age $=20.82$ [SD=2.09] years) was performed to verify the examiner's calibration for measuring weight and height. Intra examiner reproducibility was estimated using the Intraclass Correlation Coefficient (ICC) and good values were found (weight: ICC $=0.979$ [95\% Cl=0.974-0.983], height: ICC $=0.968$ $[95 \% \mathrm{Cl}=0.957-0.976])$.

\section{Procedures}

First, the higher education institution (UNESP) authorized data collection among students. In sequence, the data collection was scheduled with the professors of the Pharmacy-Biochemistry course in the classroom. Students completed characterization questions in the presence of the teacher. After, students' weight and height were measured in a reserved environment where they also chose the figures using the FRS. Only students older than 18 years that agreed to participate and signed the Informed Consent were included in the study sample.

\section{Ethical Aspects}

The study was approved by the Human Research Ethics Committee of the School of Pharmaceutical Sciences (CAAE: 42105415.0.0000.5426).

\section{Statistical Analysis}

The prevalence of distortion and dissatisfaction with body size was calculated with a $95 \% \mathrm{Cl}$. The chi-square test $\left(\chi^{2}\right)$ was used to evaluate the relationship of both distortion and dissatisfaction with body size with the demographic and academic variables and the anthropometric nutritional status. The significance level of 5\% was adopted. The software IBM SPSS Statistics (V.22, IMB Company, Chicago, IL) was used for the analyses.

\section{RESULTS}

The final sample consisted of 356 students (female $=71.63 \%$ ), with a mean age of $20.95(S D=2.55)$. The students' mean BMI was $23.17(S D=4.08) \mathrm{kg} / \mathrm{m}^{2}$ (male=24.13 [SD=4.20] $\mathrm{kg} / \mathrm{m}^{2}$, female $\left.=22.80[S D=4.00] \mathrm{kg} / \mathrm{m}^{2}\right)$. Table 1 presents the characteristics of the sample.

The mean value found for distortion with body size among students was of 0.23 (SD=3.79) $\mathrm{kg} / \mathrm{m} 2$ (male $=0.32[\mathrm{SD}=3.86] \mathrm{kg} / \mathrm{m} 2$, female $=0.18[\mathrm{SD}=3.77] \mathrm{kg} / \mathrm{m} 2)$. The mean value found for dissatisfaction with body size was of $0.60(\mathrm{SD}=4.66) \mathrm{kg} / \mathrm{m} 2$ (male=-1.26 [SD=4.62] kg/m2, female $=-0.34[\mathrm{SD}=4.66] \mathrm{kg} / \mathrm{m} 2$ ). Table 2 presents the prevalence of the distortion with body size among students.

The prevalence of distortion with body size among students was influenced by the method used. In the original, all participants showed some level of distortion with body size. On the other hand, in the alternative 96 students presented non-problematic body distortion.

Regarding dissatisfaction with body size, the prevalence was $79.49 \%$ with $95 \% \mathrm{Cl}$ ranging from 75.30 to $83.68 \%$ (male $=80.20 \%$ [95\% Cl=72.28-88.12], female $=79.21 \%$ [95\% Cl=74.21-84.21]). Among dissatisfied individuals, 58.66\% (95\% $\mathrm{Cl}=52.92-64.40)$ wished to decrease body size (male=46.91\% [95\% Cl=36.28-57.84], female=63.36 [95\% Cl=56.70-70.02]). 
Table 3 presents the associations between the variables of interest with the presence or absence of distortion and dissatisfaction with body size.

Table 1. Characteristics of the sample

\begin{tabular}{|c|c|c|}
\hline Characteristic & $\mathbf{n}$ & $\%$ \\
\hline \multicolumn{3}{|l|}{ Economic class } \\
\hline A (high) & 105 & 29.67 \\
\hline B (medium) & 194 & 54.80 \\
\hline C (low) & 55 & 15.53 \\
\hline \multicolumn{3}{|c|}{ Labor activity together with studies } \\
\hline Yes & 28 & 7.88 \\
\hline No & 327 & 92.12 \\
\hline \multicolumn{3}{|l|}{ Course year } \\
\hline First & 83 & 23.31 \\
\hline Second & 65 & 18.26 \\
\hline Third & 85 & 23.88 \\
\hline Fourth & 56 & 15.73 \\
\hline Fifth & 67 & 18.82 \\
\hline \multicolumn{3}{|l|}{ Study schedule } \\
\hline Full-time & 257 & 73.01 \\
\hline Night & 95 & 26.99 \\
\hline \multicolumn{3}{|c|}{ Use of medications to change the body } \\
\hline Yes & 35 & 9.83 \\
\hline No & 321 & 90.17 \\
\hline \multicolumn{3}{|l|}{ The medications were to: } \\
\hline Gain weight & 8 & 22.86 \\
\hline Lose weight & 18 & 51.43 \\
\hline To gain muscle mass & 9 & 25.71 \\
\hline \multicolumn{3}{|c|}{ Use of dietary supplements to change the body } \\
\hline Yes & 86 & 24.16 \\
\hline No & 270 & 75.84 \\
\hline \multicolumn{3}{|c|}{ The dietary supplements were to: } \\
\hline Gain weight & 19 & 22.09 \\
\hline Lose weight & 20 & 23.26 \\
\hline To gain muscle mass & 47 & 54.65 \\
\hline \multicolumn{3}{|c|}{ Engagement in physical activities } \\
\hline Yes & 161 & 45.48 \\
\hline No & 193 & 54.52 \\
\hline \multicolumn{3}{|c|}{ Anthropometric nutritional status } \\
\hline Underweight & 31 & 8.71 \\
\hline Eutrophic & 226 & 63.48 \\
\hline Overweight/Obesity & 99 & 27.81 \\
\hline
\end{tabular}

Table 2. Prevalence of the distortion with body size among participants considering two analytical strategies (original and alternative)

\begin{tabular}{|c|c|c|c|c|}
\hline \multirow{3}{*}{ Distortion with body size } & \multicolumn{4}{|c|}{ Method } \\
\hline & \multicolumn{2}{|c|}{ Original' $^{1}$} & \multicolumn{2}{|c|}{ Alternative $^{2}$} \\
\hline & $\%(n)$ & $95 \% \mathrm{Cl}$ & $\%(n)$ & $95 \% \mathrm{Cl}$ \\
\hline Absence & - & - & - & - \\
\hline Normative & - & - & $26.97(96)$ & $22.35-31.59$ \\
\hline Present - Underestimate & $47.75(170)$ & $42.55-52.95$ & $34.83(124)$ & $29.87-39.79$ \\
\hline Present - Overestimate & $52.25(186)$ & $47.05-57.45$ & $38.20(136)$ & $33.15-43.25$ \\
\hline
\end{tabular}


Note. 1 Proposed by the Kakeshita et al. (2009). ${ }^{2}$ Considering variation values of up to $\pm 1.25 \mathrm{~kg} / \mathrm{m}^{2}$ as normative. $95 \% \mathrm{Cl}=95 \%$ confidence interval.

Table 3. Association between the variables of interest with the presence or absence of distortion and dissatisfaction with body size.

\begin{tabular}{|c|c|c|c|c|c|c|c|c|}
\hline \multirow{2}{*}{ Variable } & \multicolumn{4}{|c|}{ Distortion with body size $^{1}$} & \multicolumn{4}{|c|}{ Dissatisfaction with body size } \\
\hline & Absence & Presence & $x^{2}$ & $p$ & Absence & Presence & $x^{2}$ & $p$ \\
\hline \multicolumn{9}{|l|}{ Sex } \\
\hline Male & 26 & 75 & 0.038 & 0.845 & 20 & 81 & 0.004 & 0.951 \\
\hline Female & 70 & 185 & & & 53 & 202 & & \\
\hline \multicolumn{9}{|l|}{ Economic class } \\
\hline A (high) & 30 & 75 & 0.889 & 0.641 & 26 & 79 & 1.904 & 0.386 \\
\hline $\mathrm{B}$ (medium) & 53 & 141 & & & 35 & 159 & & \\
\hline C (low) & 12 & 43 & & & 11 & 44 & & \\
\hline \multicolumn{9}{|l|}{$\begin{array}{l}\text { Labor activity together } \\
\text { with studies }\end{array}$} \\
\hline Yes & 8 & 20 & 0.000 & 0.998 & 8 & 20 & 0.720 & 0.396 \\
\hline No & 87 & 240 & & & 65 & 262 & & \\
\hline \multicolumn{9}{|l|}{ Course year } \\
\hline First & 22 & 61 & 2.681 & 0.612 & 12 & 71 & 5.116 & 0.276 \\
\hline Second & 21 & 44 & & & 11 & 54 & & \\
\hline Third & 18 & 67 & & & 19 & 66 & & \\
\hline Fourth & 15 & 41 & & & 12 & 44 & & \\
\hline Fifth & 20 & 47 & & & 19 & 48 & & \\
\hline \multicolumn{9}{|l|}{ Study schedule } \\
\hline Full-time & 75 & 182 & 1.932 & 0.164 & 53 & 204 & 0.002 & 0.984 \\
\hline Night & 20 & 75 & & & 19 & 76 & & \\
\hline \multicolumn{9}{|l|}{$\begin{array}{l}\text { Use of medications to } \\
\text { change the body }\end{array}$} \\
\hline Yes & 8 & 27 & 0.142 & 0.707 & 4 & 31 & 1.393 & 0.238 \\
\hline No & 88 & 233 & & & 69 & 252 & & \\
\hline \multicolumn{9}{|l|}{$\begin{array}{l}\text { Use of dietary } \\
\text { supplements to change } \\
\text { the body }\end{array}$} \\
\hline Yes & 21 & 65 & 0.223 & 0.637 & 18 & 68 & 0.002 & 1.000 \\
\hline No & 75 & 195 & & & 55 & 215 & & \\
\hline \multicolumn{9}{|l|}{$\begin{array}{c}\text { Engagement in physical } \\
\text { activities }\end{array}$} \\
\hline Yes & 41 & 120 & 0.169 & 0.681 & 36 & 125 & 0.368 & 0.544 \\
\hline No & 54 & 139 & & & 37 & 156 & & \\
\hline \multicolumn{9}{|l|}{$\begin{array}{l}\text { Anthropometric } \\
\text { nutritional status }\end{array}$} \\
\hline Underweight & 15 & 16 & 9.523 & $0.009 *$ & 2 & 29 & 16.163 & $<0.001 *$ \\
\hline Eutrophic & 61 & 165 & & & 61 & 165 & & \\
\hline Overweight/ Obesity & 20 & 79 & & & 10 & 89 & & \\
\hline
\end{tabular}

Note. ${ }^{1}$ Distortion with body size was obtained using an analytical strategy considering the variation of values up to $\pm 1.25 \mathrm{~kg} / \mathrm{m}^{2}$ as "normative distortion with body size" and the other values as "distortion with body size". $\chi^{2}=$ chi-square test. * $p<0.05$

There was a significant relationship between anthropocentric nutritional status and both distortion and dissatisfaction with body size. Among individuals classified as eutrophic or overweight/obesity, there was a high prevalence of distortion with body size. Among students classified as underweight or overweight/obesity, there was a high dissatisfaction with body size.

Table 4 presents the distribution of participants that presented distortion $(n=260)$ or dissatisfaction $(n=283)$ with the body size and their association with the variables of interest. 
Table 4. Association between distortion and dissatisfaction type with body size and variables of interest

\begin{tabular}{|c|c|c|c|c|c|c|c|c|}
\hline \multirow{2}{*}{ Characteristic } & \multicolumn{4}{|c|}{ Distortion with body size $^{1}$} & \multicolumn{4}{|c|}{ Dissatisfaction with body size } \\
\hline & \multirow{2}{*}{\multicolumn{2}{|c|}{ Underestimate Overestimate }} & & \multirow[t]{2}{*}{$p$} & \multirow{2}{*}{\multicolumn{2}{|c|}{ Decrease Increase }} & \multirow[t]{2}{*}{$\chi^{2}$} & \multirow[t]{2}{*}{$p$} \\
\hline Sex & & & & & & & & \\
\hline Male & 55 & 20 & 26.353 & $<0.001 *$ & 38 & 43 & 5.793 & $0.016^{*}$ \\
\hline Female & 69 & 116 & & & 128 & 74 & & \\
\hline \multicolumn{9}{|l|}{ Economic class } \\
\hline A (high) & 38 & 37 & 0.331 & 0.848 & 48 & 31 & 1.813 & 0.404 \\
\hline B (medium) & 66 & 75 & & & 88 & 71 & & \\
\hline C (low) & 20 & 23 & & & 29 & 15 & & \\
\hline \multicolumn{9}{|l|}{$\begin{array}{l}\text { Labor activity } \\
\text { together with } \\
\text { studies }\end{array}$} \\
\hline Yes & 11 & 9 & 0.201 & 0.654 & 9 & 11 & 1.148 & 0.284 \\
\hline No & 113 & 127 & & & 157 & 105 & & \\
\hline \multicolumn{9}{|l|}{ Course year } \\
\hline First & 32 & 29 & 8.418 & 0.077 & 34 & 37 & 8.129 & 0.087 \\
\hline Second & 15 & 29 & & & 36 & 18 & & \\
\hline Third & 29 & 38 & & & 42 & 24 & & \\
\hline Fourth & 26 & 15 & & & 22 & 22 & & \\
\hline Fifth & 22 & 25 & & & 32 & 16 & & \\
\hline \multicolumn{9}{|l|}{ Study schedule } \\
\hline Full-time & 83 & 99 & 0.981 & 0.322 & 120 & 84 & 0.001 & 0.997 \\
\hline Night & 40 & 35 & & & 44 & 32 & & \\
\hline \multicolumn{9}{|l|}{$\begin{array}{c}\text { Use of } \\
\text { medications to } \\
\text { change the } \\
\text { body }\end{array}$} \\
\hline Yes & 14 & 13 & 0.064 & 0.800 & 19 & 12 & 0.015 & 0.903 \\
\hline No & 110 & 123 & & & 147 & 105 & & \\
\hline \multicolumn{9}{|l|}{$\begin{array}{l}\text { Use of dietary } \\
\text { supplements to } \\
\text { change the } \\
\text { body }\end{array}$} \\
\hline Yes & 39 & 26 & 4.625 & $0.032 *$ & 35 & 33 & 1.536 & 0.215 \\
\hline No & 85 & 110 & & & 131 & 84 & & \\
\hline \multicolumn{9}{|l|}{$\begin{array}{c}\text { Engagement in } \\
\text { physical } \\
\text { activities }\end{array}$} \\
\hline Yes & 66 & 54 & 4.511 & $0.034 *$ & 71 & 54 & 0.327 & 0.567 \\
\hline No & 57 & 82 & & & 95 & 61 & & \\
\hline \multicolumn{9}{|l|}{$\begin{array}{c}\text { Anthropometric } \\
\text { nutritional } \\
\text { status }\end{array}$} \\
\hline Underweight & 12 & 4 & 9.054 & $0.011 *$ & - & 29 & 89.833 & $<0.001$ * \\
\hline Eutrophic & 83 & 82 & & & 83 & 82 & & \\
\hline $\begin{array}{l}\text { Overweight/ } \\
\text { Obesity }\end{array}$ & 29 & 50 & & & 83 & 6 & & \\
\hline
\end{tabular}

Note. ${ }^{1}$ Distortion with body size was obtained using an analytical strategy considering the variation of values up to $\pm 1.25 \mathrm{~kg} / \mathrm{m}^{2}$ as "normative distortion with body size" and the other values as "distortion with body size". $\chi^{2}=$ chi-square test. * $p<0.05$

The distortion type with body size had significant association with sex, dietary supplements intake, engagement in physical activities, and anthropometric nutritional status. Men underestimated the body size while women overestimated it. The proportion of individuals who underestimated the body size was higher among students that did not use 
dietary supplements and those who reported practicing physical activity. Students classified as underweight underestimated body size and those classified as overweight/obesity overestimated it. The dissatisfaction type with body size had significant association with anthropometric nutritional status and sex. Students classified as underweight wished to increase body size while those classified as overweight/obesity wished to decrease it. Men wished to increase body size while women wished to decrease.

\section{DISCUSSION}

This study aimed to present the prevalence of distortion and dissatisfaction with body size among university students and its relation with the demographic and academic characteristics and the anthropometric nutritional status of participants. We also tested an analytical strategy to identify the distortion with body size that considers a normative range between the mean BMI differences corresponding to each figure of the Brazilian FRS. Demographic characteristics and anthropometric nutritional status were associated with both distortion and dissatisfaction with body size.

Most students were unable to perceive their current body size and reported high dissatisfaction (79.5\% [95\% Cl=75.3-83.7]). This result confirms those of the studies presented by Coqueiro et al. (2008) (78.8\% [95\% Cl=73.8-83.8]), Martins et al., (2012) (77.9\% [95\% Cl=75.1-80.7]), Miranda et al. (2012) (76.6\% [95\% Cl=73.1-80.1]), and Radwan et al. (2019) (81.0\% [95\% Cl=76.6-85.4]). Further, the high prevalence of dissatisfaction with body size found in our study was related to the wish to decrease body size, and this corroborates the literature (Bosi et al., 2006; Dumith et al., 2012; Radwan et al., 2019). The cultural and social pressures suffered by students, especially among women, to adapt to aesthetic standards may justify our findings (Demarest \& Allen, 2000; Adami et al., 2008; Cash \& Smolak, 2011; Grogan, 2016).

For the distortion with body size, our results showed that this aspect was influenced by the analytical strategy used. The alternative analytical method considered that small deviations from the visualization of figures about body size can be "normative" or "non-problematic" (Campos et al., 2020). From this strategy, we found that $26.97 \%$ of the sample presented a "normative distortion with body size" suggesting that these students did not evaluate their body negatively. Gardner and Brown (2010) state that choosing a specific figure of the silhouette without considering variability can lead to errors. Furthermore, these authors reported that the scales of figures and silhouettes, generally, overestimate the prevalence of negative body image. Kling et al. (2019) highlighted that the silhouette measures used to investigate body image consider rating one's ideal body or ideal-actual discrepancy from abstract figures rather than the individual's own body, which can cause bias. In this way, scales of figures and silhouettes should not be used exclusively to assess individual's body image, being necessary to develop protocols with the inclusion of other psychometric instruments and/or investigation methods, such as adjustable mirror and TV-video procedure (Gardner et al., 1998).

We found a significant association between the participants' anthropometric nutritional status and both distortion and dissatisfaction with body size. The literature has shown that individuals, classified from BMI, as underweight, overweight or obese are more susceptible to negative body image (Bosi et al., 2006; Neighbors \& Sobal, 2007; Nikniaz et al., 2016; Silva et al., 2017; Radwan et al., 2019). This finding may be related to the fact that individuals with BMI outside of "normal" suffer the greater social pressure to achieve the body type considered as "ideal" and may develop a more critical look on their image, which can result in distortion and/or dissatisfaction with body size (Bosi et al., 2006; Neighbors \& Sobal, 2007; Radwan et al., 2019). The prevalence of body dissatisfaction found among eutrophic individuals also should be mentioned. This fact indicates that not only students with such "nonstandard body sizes" (i.e., underweight, overweight, and obese) are concerned with the body. We believe that negative assessment of the body can influence different areas of the student's life; therefore, clinicians (e.g., nutritionists and psychologists) should to evaluate 
carefully individuals dissatisfied with the body, as they are more likely to develop harmful behaviors, such as eating restriction (Silva et al., 2018).

Regarding the type of body dissatisfaction, the individuals classified as underweight wished mainly to increase body size and the students classified as overweight/obesity wished to decrease their silhouette. These results corroborate the literature (Coqueiro et al., 2008; Bosi et al., 2006; Miranda et al., 2012; Dumith et al., 2012; Radwan et al., 2019). These studies have shown that people dissatisfied with the body adopt different strategies to change it according to socially accepted aesthetic standards. The association found in our study between the type of distortion with body size and anthropometric nutritional status also was reported by Kakeshita \& Almeida (2006). This finding shows that individuals classified as overweight/obese overestimate body size, while people classified as underweight underestimate it.

Significant relationships between distortion and dissatisfaction with body size and sex were found verified in this study corroborating the findings of Austin et al. (2017), Cubrelati et al. (2014), and Laus et al. (2009). These studies reported that women presented a higher prevalence of distortion and/or dissatisfaction with body size compared to men. In this way, it is worth mentioning that there are differences regarding the desired body pattern for both sexes. For women, the idealized body is generally associated with thinner shape, while for men the bulkier shape is valued in the upper body (Adami et al., 2008; Austin et al., 2009; Demarest \& Allen, 2000; Grogan, 2016; Muth \& Cash, 1997; Quittkat et al., 2019). This pattern also was identified in our study, which reveals the need to develop psychoeducational strategies regarding body image separately for men and women.

Still, we found a higher prevalence of body size underestimation among students who practiced physical activity and used dietary supplements to change their bodies. Previous studies (Silva et al., 2020; Laus et al., 2009; Silva et al., 2017) have also found similar results to our, revealing that individuals who practice excessive physical activity and intake food supplements indiscriminately generally are dissatisfied with the body. In this way, these people are susceptible to the adoption of dysfunctional behaviors, such as disordered eating behavior and social isolation. Thus, these characteristics should be included in preventive and educational protocols to reduce the risk of developing psychopathologies, such as eating disorders and depression.

The results of this study should be analyzed with caution since there are limitations. First, this cross-sectional study does not allow establishing a cause-and-effect relationship between the variables. Second, we used a non-probabilistic university sample that limits the validity of results for different contexts. Third, we use a scale of figures and silhouettes to assess students' distortion with body size, but this instrument is limited to investigate the perceptive dimension of body image. Thus, we suggest that future protocols consider using other methods to investigate the people's body perception aiming to produce more accurate results. Despite these limitations, the results of this study can assist clinicians and researchers in planning education, prevention and treatment strategies focused on body image disorders in clinical and epidemiological contexts.

\section{CONCLUSION}

A high prevalence of distortion and dissatisfaction with body size was found among university students. An analytical strategy to identify the distortion with body size from the use of a Brazilian Figure Rating Scale was used in our study and this considered small variations in BMI values as normative. Distortion with body size was related to sex, dietary supplements intake, the practice of physical activity, and anthropometric nutritional status. Dissatisfaction with body size was related only to the sex and anthropometric nutritional status. These characteristics are relevant for future investigations on individuals' body image. 


\section{ACKNOWLEDGMENTS}

The São Paulo Research Foundation (FAPESP, grant \#2015/02525-9) for the financial support.

\section{REFERENCES}

Adami F, Frainer DES, Santos JS, Fernandes TC, Oliveira FR. Insatisfação corporal e atividade física em adolescentes da região continental de Florianópolis. Psicol, Teor Pesqui. 2008;24(2):143-9. http://dx.doi.org/10.1590/S0102-37722008000200003.

Amaral ACS, Ferreira MEC. Body dissatisfaction and associated factors among Brazilian adolescents: A longitudinal study. Body Image. 2017;22(3):32-8. http://dx.doi.org/10.1016/j.bodyim.2017.04.006. PMid:28570920.

Associação Brasileira de Empresas de Pesquisa - ABEP. Critério de classificação econômica Brasil 2015. São Paulo: ABEP; 2015 [cited 2020 Jun 01]. Available from: http://www.abep.org/criterio-brasil

Austin JL, Serier KN, Sarafin RE, Smith JE. Body dissatisfaction predicts poor behavioral weight loss treatment adherence in overweight Mexican American women. Body Image. 2017;23(4):155-61. http://dx.doi.org/10.1016/j.bodyim.2017.08.002. PMid:29035748.

Austin SB, Haines J, Veugelers PJ. Body satisfaction and body weight: gender differences and sociodemographic determinants. BMC Public Health. 2009;9(1):1-7. http://dx.doi.org/10.1186/14712458-9-313. PMid:19712443.

Banfield SS, McCabe MP. An evaluation of the construct of body image. Adolescence. 2002;37(146):37393. PMid:12144166.

Bosi MLM, Luiz RR, Morgado CDC, Costa MDS, Carvalho RD. Autopercepção da imagem corporal entre estudantes de nutrição: um estudo no município do Rio de Janeiro. J Bras Psiquiatr. 2006;55(2):10813. http://dx.doi.org/10.1590/S0047-20852006000200003.

Brasil. Ministério da Saúde. Secretaria de Atenção à Saúde. Departamento de Atenção Básica. Coordenação-Geral de Alimentação e Nutrição. Orientações para a coleta e análise de dados antropométricos em serviços de saúde: norma técnica do sistema de vigilância alimentar e nutricional - SISVAN. Brasília: Ministério da Saúde; 2011 [cited 2020 Jul 7]. Available from: https://pesquisa.bvsalud.org/bvsms/resource/pt/mis-34822

Campos JADB, Martins BG, Navarro FM, Oliveira AP, Costa J. Distorção e insatisfação com o tamanho do corpo de adultos jovens. In: Tescarollo IL, editor. Farmácia e promoção da saúde 2. Ponta Grossa: Atena Editora; 2020. p. 135-150. http://dx.doi.org/10.22533/at.ed.25220030216.

Carvalho PHB, Alvarenga MS, Ferreira MEC. An etiological model of disordered eating behaviors among Brazilian women. Appetite. 2017;116:164-72. http://dx.doi.org/10.1016/j.appet.2017.04.037. PMid:28478061.

Cash TF, Morrow JA, Hrabosky Jl, Perry AA. How has body image changed? A cross-sectional investigation of college women and men from 1983 to 2001. J Consult Clin Psychol. 2004;72(6):1081-9. http://dx.doi.org/10.1037/0022-006X.72.6.1081. PMid:15612854.

Cash TF, Smolak L. Body Image: a handbook of science, practice, and prevention. New York: The guilford Press; 2011.

Coqueiro RD, Petroski EL, Pelegrini A, Barbosa AR. Insatisfação com a imagem corporal: avaliação comparativa da associação com estado nutricional em universitários. Rev Psiquiatr Rio Gd Sul. 2008;30(1):31-8. http://dx.doi.org/10.1590/S0101-81082008000100009.

Cubrelati BS, Rigoni PAG, Vieira LF, Belem IC. Relação entre distorção de imagem corporal e risco de desenvolvimento de transtornos alimentares em adolescentes. Conexões. 2014;12(1):1-15.

Demarest J, Allen R. Body image: gender, ethnic, and age differences. J Soc Psychol. 2000;140(4):465-72. http://dx.doi.org/10.1080/00224540009600485. PMid:10981375.

Dumith SC, Menezes AMB, Bielemann RM, Petresco S, Silva ICM, Linhares RS, Amorim TC, Duarte DV, Araújo CLP, Santos JV. Insatisfação corporal em adolescentes: um estudo de base populacional. Cien Saude Colet. 2012;17(9):2499-505. http://dx.doi.org/10.1590/S1413-81232012000900030. PMid:22996900.

Gardner RM, Brown DL. Body image assessment: a review of figural drawing scales. Pers Individ Dif. 2010;48(2):107-11. http://dx.doi.org/10.1016/j.paid.2009.08.017. 
Gardner RM, Friedman BN, Jackson NA. Methodological concerns when using silhouettes to measure body image. Percept Mot Skills. 1998;86(2):387-95. http://dx.doi.org/10.2466/pms.1998.86.2.387. PMid:9638738.

Grogan S. Body image: understanding body dissatisfaction in men, women and children (Vol. 3). London: Routledge; 2016. http://dx.doi.org/10.4324/9781315681528.

Hosseini SA, Padhy RK. Body image distortion. Treasure Island (FL): StatPearls Publishin; 2019.

Kakeshita I, Silva A, Zanatta D, Almeida S. Construção e fidedignidade teste-reteste de escalas de silhuetas brasileiras para adultos e crianças. Psicol, Teor Pesqui. 2009;25(2):263-70. http://dx.doi.org/10.1590/S0102-37722009000200015.

Kakeshita IS, Almeida SS. Relação entre índice de massa corporal e a percepção da auto-imagem em universitários. Rev Saude Publica. 2006;40(3):497-504. http://dx.doi.org/10.1590/S003489102006000300019 . PMid:16810375.

Kling J, Kwakkenbos L, Diedrichs PC, Rumsey N, Frisen A, Brandao MP, Silva AG, Dooley B, Rodgers RF, Fitzgerald A. Systematic review of body image measures. Body Image. 2019;30:170-211. http://dx.doi.org/10.1016/j.bodyim.2019.06.006. PMid:31394462.

Laus MF, Costa TMB, Almeida SS. Distorção da imagem corporal em adolescentes: um estudo de comparação entre dois instrumentos. Medic Ribeirão Preto. 2009;42(3):358-65. http://dx.doi.org/10.11606/issn.2176-7262.v42i3p358-365.

Martins CR, Gordia AP, Silva DAS, Quadros TD, Ferrari EP, Teixeira DM, Petroski EL. Insatisfação com a imagem corporal e fatores associados em universitários. Estud Psicol. 2012;17(2):241-6. http://dx.doi.org/10.1590/S1413-294X2012000200007.

Maruf FA, Akinpelu AO, Udoji NV. Differential perceptions of body image and body weight among adults of different socioeconomic status in a sub-urban population. J Biosoc Sci. 2014;46(3):279-93. http://dx.doi.org/10.1017/S002193201300028X. PMid:23721833.

Miranda VPN, Filgueiras JF, Neves CM, Teixeira PC, Ferreira MEC. Insatisfação corporal em universitários de diferentes áreas de conhecimento. J Bras Psiquiatr. 2012;61(1):25-32. http://dx.doi.org/10.1590/S0047-20852012000100006.

Modoio VB, Antunes HKM, Gimenez PRB, Santiago MLDM, Tufik S, Mello MT. Negative addiction to exercise: are there differences between genders. Clinics (São Paulo). 2011;66(2):255-60. http://dx.doi.org/10.1590/S1807-59322011000200013. PMid:21484043.

Muth JL, Cash TF. Body-image attitudes: what differences does gender make? J Appl Soc Psychol. 1997;27(16):1438-52. http://dx.doi.org/10.1111/j.1559-1816.1997.tb01607.x.

Neighbors LA, Sobal J. Prevalence and magnitude of body weight and shape dissatisfaction among university students. Eat Behav. 2007;8(4):429-39. http://dx.doi.org/10.1016/j.eatbeh.2007.03.003. PMid:17950931.

Nikniaz Z, Mahdavi R, Amiri S, Ostadrahimi A, Nikniaz L. Factors associated with body image dissatisfaction and distortion among Iranian women. Eat Behav. 2016;22(1):5-9. http://dx.doi.org/10.1016/j.eatbeh.2016.03.018. PMid:27046301.

Onis M, Onyango AW, Borghi E, Siyam A, Nishida C, Siekmann J. Development of a WHO growth reference for school-aged children and adolescents. Bull World Health Organ. 2007;85(9):660-7. http://dx.doi.org/10.2471/BLT.07.043497. PMid:18026621.

Pelegrini A, Petroski E. The association between body dissatisfaction and nutritional status in adolescents. Human Mov. 2010;11(1):51-7. http://dx.doi.org/10.2478/v10038-010-0001-7.

Pereira ÉF, Graup S, Lopes ADS, Borgatto AF, Daronco LSE. Percepção da imagem corporal de crianças e adolescentes com diferentes níveis socio-econômicos na cidade de Florianópolis, Santa Catarina, Brasil. Rev Bras Saúde Mater Infant. 2009;9(3):253-62. http://dx.doi.org/10.1590/S151938292009000300004.

Quittkat HL, Hartmann AS, Dusing R, Buhlmann U, Vocks S. Body Dissatisfaction, Importance of Appearance, and Body Appreciation in Men and Women Over the Lifespan. Front Psychiatry. 2019;10:1-12. http://dx.doi.org/10.3389/fpsyt.2019.00864. PMid:31920737.

Radwan H, Hasan HA, Ismat H, Hakim H, Khalid H, Al-Fityani L, Mohammed R, Ayman A. Body mass index perception, body image dissatisfaction and their relations with weight-related behaviors among university students. Int J Environ Res Public Health. 2019;16(1541):1-11. http://dx.doi.org/10.3390/ijerph16091541. PMid:31052368. 
Scagliusi FB, Alvarenga M, Polacow VO, Cordás TA, de Oliveira Queiroz GK, Coelho D, Philippi ST, Lancha $\mathrm{AH}$ Jr. Concurrent and discriminant validity of the Stunkard's figure rating scale adapted into Portuguese. Appetite. 2006;47(1):77-82. http://dx.doi.org/10.1016/j.appet.2006.02.010. PMid:16750589.

Scherer FC, Martins CR, Pelegrini A, Matheus SC, Petroski EL. Imagem corporal em adolescentes: associação com a maturação sexual e sintomas de transtornos alimentares. J Bras Psiquiatr. 2010;59(3):198-202. http://dx.doi.org/10.1590/S0047-20852010000300005.

Schumacher LM, Dal Bosco SM, Conde SR. Estado nutricional e comportamento alimentar associado ao rendimento escolar de adolescentes. ConScientiae Saúde. 2010;9(1):87-96. http://dx.doi.org/10.5585/conssaude.v9i1.2146.

Silva WR, Marôco J, Campos JADB. Strategies for eating and body change among Brazilian women and men. Trends Psychiatry Psychother. 2020;42(1):16-29. http://dx.doi.org/10.1590/2237-6089-20190010. PMid:32321082.

Silva WRD, Campos JADB, Marôco J. Impact of inherent aspects of body image, eating behavior and perceived health competence on quality of life of university students. PLoS One. 2018;13(6):e0199480. http://dx.doi.org/10.1371/journal.pone.0199480. PMid:29933390.

Silva WRD, Santana MS, Maroco J, Maloa BFS, Campos J. Body weight concerns: cross-national study and identification of factors related to eating disorders. PLoS One. 2017;12(7):e0180125. http://dx.doi.org/10.1371/journal.pone.0180125. PMid:28686602.

Stunkard AJ, Sørensen T, Schulsinger F. Use of the Danish Adoption Register for the study of obesity and thinness. Res Publ Assoc Res Nerv Ment Dis. 1983;60(1):115-20. PMid:6823524.

Tallat N, Fatima A, Fiza K, Adiya D. Body's image concerns and its impact on academic achievements. Journal of Psychology and Clinical Psychiatry. 2017;7(3):00437. http://dx.doi.org/10.15406/jpcpy.2017.07.00437.

World Health Organization - WHO. Noncommunicable diseases country profiles. Geneva: WHO; 2018. Technical report [cited 2020 Jul 7]. Available from: https://www.who.int/publications/i/item/9789241514620

World Health Organization - WHO. Obesity: preventing and managing the global epidemic. Geneva: Switzerland; 2000. Technical report [cited 2020 Mar 02]. Available from: https://www.who.int/nutrition/publications/obesity/WHO_TRS_894/en/

Xavier GS, Pasian SR, Almeida SS. Assessment of Body Image: instruments Available in Brazil. Psico-USF. 2015;201520(3):529-45. http://dx.doi.org/10.1590/1413-82712015200314.

Yahia N, El-Ghazale H, Achkar A, Rizk S. Dieting practices and body image perception among Lebanese university students. Asia Pac J Clin Nutr. 2011;20(1):21-8. PMid:21393106.

\section{Author contributions:}

AS: conceptualization, methodology, formal analysis, investigation, resources, data curation, writing - original draft preparation, funding acquisition; WRS: conceptualization, methodology, validation, investigation, writing - review \& editing, visualization; MSS: conceptualization, methodology, formal analysis, writing - original draft preparation; JADBC: conceptualization, methodology, validation, writing - review \& editing, supervision, project administration, funding acquisition. 